\title{
Standard-Based Teaching Quality Assessment
}

\author{
Shuang $Z \mathrm{HANG}^{1, \mathrm{a}}$, Qinghe $\mathrm{HU}^{2, \mathrm{~b}}$ \\ ${ }^{1}$ Software College, Northeastern University, Shenyang 110819, China; \\ ${ }^{2}$ College of Information Science and Engineering, Northeastern University, Shenyang 110819, \\ China \\ a zhangs@swc.neu.edu.cn, ${ }^{\mathrm{b}}$ huqinghe@ise.neu.edu.cn
}

Keywords: teaching quality analysis; teaching quality assessment; course standard; Bloom's Taxonomy of Educational Objectives.

\begin{abstract}
In recent years, countries around the world emphasis more and more on the research and practice on the assessment of teaching quality. Teaching assessment has become an efficient method for educational administration. Curriculum standard provides a reference for teaching quality and learning effectiveness analysis. The authors adopt Bloom's Taxonomy of Educational Objectives to parse the contents of curriculum standards. It adopts two dimensions, knowledge and cognitive process, to analyze and determine the standards of each knowledge point. Therefore, it can provide reference for assessment dimensions of teaching quality and learning effectiveness. It sets rules for not only curriculum contents and scope but also cognition degree. Standard-based assessment can guarantee assessment reasonable and traceable, and consistent with curriculum standards and teaching practice.
\end{abstract}

\section{International experience of education quality assessment}

Governments all over the world are paying more and more attention to education quality. It has nowadays become a major education reforming trend to use scientific assessment to get complete and true evaluation of education quality and students development to provide better decision basis for education reforming, to provide reference for students' personal and sustainable development. Some foreign countries have done a great deal of theoretical research and practical exploration in the field of student academic achievement assessment. Student achievement refers the result of student learning, that is to say, the achievement is the learning results of individual students by measuring and assessing.

The international main organizations to develop and promote student academic achievement are IEA (International Association for the Evaluation of Education Achievement) and OECD (Organization for Economic Co-operation and Development). Currently, tens of counties and regions participates in these two organizations, including NAEP (National Assessment of Educational Progress) of the United States, APU (PISA Organization) in England, National Research Survey in Japan, periodic national regular revision in Australia, New Zealand, Switzerland and other countries, exc.

\section{Situation of education quality evaluation in China}

In China, many higher education experts and learners have done thorough and useful research and exploration on high education quality. They try to get multi-level and multi-angle assessing education management and teaching process. But many of them are based on all kinds of investigation data of teaching, some investigation data can only be collected after a period after the teaching. And these survey data are mainly subjective graded by all kinds of personnel's, lacking clear guidelines and standards. So the teaching quality analysis is mostly subjective and qualitative. And some data can be collected only when it go through a period of time, even after the students' graduation. There will be a time lag.[2-4] The qualitative, subjective and time-lagging teaching quality assessment can provide reference for macro teaching and training system and teaching management. But, they would be somewhat general, vague and late for the first-line teachers; they also lack specific, quantitative and accurate positioning analysis and assessment data. It cannot 
provide actual guidance and reference. To solve this problem, based on years of teaching experience and research on curriculum standards, the author proposes a standard-based quality assessment method for higher education, to achieve in-time teaching quality assessment, to provide in-time, accurate and scientific basis for the next-round teaching design and implementation.

\section{Curriculum standards}

It has become a trend of international education reforming to design and implement teaching based on curriculum standards. Curriculum standard rose in American education. Some American learners studied the integrity between standards and classroom teaching; this improves American education greatly. Other countries also joined in the research and practice on curriculum standards quickly. Curriculum standards make the rules of outcomes after a period of learning which show that expectations for students' academic achievement by the national government[5].

In recent years, some Chinese learners in basic education field have begun to concern teaching and research standards, and it has given out the corresponding curriculum standards. Curriculum standards are a major achievement of the eighth round of China's basic education curriculum reform and one of the highlights is the new curriculum. Higher research and exploration on the teaching curriculum standards have attracted the attention of some domestic educators. On National People's Congress and Chinese People's Political Consultative Conference in March 2015, the Ministry of Education put forward clearly the construction of professional standards and curriculum standards in higher education. "Now, the Ministry of Education is making professional curriculum standards. The school in the future is in accordance with this standard and set their professional standards, which is consistent with the national requirements, and can also reflect the characteristics of the school." [6].

It has been eight years since the curriculum standard was introduced into our country. However, our curriculum standards are still just documents that do not have a significant effect on teaching and quality assessment. The reason is that we lack the knowledge base in this area especially in teaching quality assessment. While, as we know it is the key problem for the current curriculum and teaching reforming. It is curriculum standard that the curriculum standards that play the largest role in assessing teachers' teaching quality and students' learning effectiveness. Curriculum standards stipulate the goal that students should achieve after completing their studying in a certain period of time. The role of curriculum standards in practice depends on the relationship between assessment and curriculum standards. If teaching quality and learning effectiveness cannot create meaningful connection with curriculum standards, it will inevitably lead to curriculum standard impossible to implement. Therefore, based on the standard of teaching quality analysis and assessment is an inevitable choice.

\section{Curriculum-based teaching design and assessment}

Curriculum standards should be the student's learning goals, and therefore they should be the most important basis for assessing teachers' teaching quality and students' learning effectiveness. The consistency between teaching practice, assessment and standards is the most important aspect and the key to guarantee the assessment is standard based.

Curriculum content standard is the refined curriculum goal. It indicates students' learning activity and contents, describes to what cognitive degree the students are supposed to master each knowledge item after studying with clear behavioral verbs and nouns.

After studying, the authors think that Bloom's Taxonomy of Educational Objectives[7] is the most suitable to parse the contents of curriculum standards. It adopts two dimensions, knowledge and cognitive process, to analyze and determine the standards of each knowledge point. For example, the content standard of knowledge point "use case modeling" is shown in Table 1. 
Table 1 Content standards of knowledge point "use-case modeling” [10]

\begin{tabular}{c|c|c|c|c|c|c}
\hline $\begin{array}{c}\text { Cognitive } \\
\text { Processes }\end{array}$ & Memory & Comprehend & Application & Analysis & Evaluation & Creation \\
\hline Knowledge
\end{tabular}

Before teaching design and implementation, teachers should develop examinational standards and think about how to assess student learning effectiveness. Assessment is a tool to promote student learning. Therefore, assessment is an integral part of teaching process. Like teaching quality, assessment quality also affects teaching quality greatly [8] .

Only after determine curriculum standards, content standards and examinational standards, should teachers begin teaching design, including syllabus, lesson plans, courseware, question bank, examination paper grouping rules, video resources, teaching resources, and etc.

\section{Curriculum-standard-based teaching quality assessment}

Based on curriculum standards, it is possible to scientifically certify student academic achievement, to detect changes in trends, to diagnose individual learning needs and to select students for higher level education. And, it can promote school, college, and department responsibility for student achievement (accountability), assess specific educational programs and policies[9]. Based on the above ideas, the authors and the team design and implement a teaching quality and learning effectiveness platform, which can provide students achievement assessment, Test effectiveness evaluation, statistics of test score, teaching quality assessment, test question diagnosis and feedback, knowledge point achievement analysis, teaching development assessment.

The author gives lecture of curriculum "Software Engineering". With the above platform, the author got quantitative assessment result of the curriculum. Due to the limitation of space, the author presents only knowledge point achievement assessment and detail table of bidirectional assessment.

\section{Conclusion}

Curriculum standards provide reference for assessment dimensions of teaching quality and learning effectiveness. It sets rules for not only curriculum contents and scope but also cognition degree. Standard-based assessment can guarantee assessment reasonable and traceable, and consistent with curriculum standards and teaching practice.

\section{References}

[1] Ma Lina, Zhang Wei. Exploration on the Reformation about the Theory and Practice of Higher Education [M]. Beijing: China Economic Press, 2013: 15. (In Chinese)

[2] Zhang Jing, Liao Xiangyang. Student Development-Oriented Quality Evaluation and Monitoring System of Higher Education [J]. China Higher Education. 2014 (1): 32-34. (In Chinese)

[3] Li min /Mao Xiaoyan. Deepening the Reform of Management Pattern to Establish Teaching Quality Monitoring System [J]. China Higher Education. 2013 (13, 14), 56-57. (In Chinese)

[4] Han Lian, Zhang Bin, Liu Shaoqin. Overall Design of Teaching Quality Monitoring System in Higher Education, China Higher Education Research, 2002 (10): 66-69. (In Chinese) 
[5] Cui Yunguo. Interpretation of National Curriculum Standards and Frameworks [J]. Global Education Outlook, 2001 (8): 4-9. (In Chinese)

[6] Sina News Center. Special of the national NPC and CPPCC in 2015[EB/OL]. http://news.sina.com.cn/c/2015-03-06/030231573853.shtml. (In Chinese)

[7] Anderson. A Taxonomy for Learning, Teaching and Assessing (A Revision of Bloom's Taxonomy of Educational Objectives) [M]. Translated by Pi Liansheng. Shanghai: East China Normal University Press, 2008. (In Chinese)

[8] Zhang Shuang, etc. Teaching Design of Software Engineering based on Curriculum Standard, Computer Education, 2014.12 (23): 102-105. (In Chinese)

[9] Cui Yunguo, Wang Shaofei, Xia Xuemei. Evaluation of Students' Academic Achievement based on Standard [M]. Shanghai: East China Normal University Press, 2012.9. (In Chinese) 